\title{
Determinants of Capital Structure in the Construction Companies across Europe and Central Asia Region
}

\author{
Asst. Prof. Dr. Hakan Bal (Beykent University, Turkey)
}

\begin{abstract}
This study examines the effects of asset tangibility, profitability, size and liquidity on capital structure (debt leverage) across the construction companies operating in in Europe and Central Asia region using the data between 1993 and 2019. The study documents that the capital structure and other financial ratios under study differ across countries, even in the same industry. Book leverage is found to be significantly negatively related to asset tangibility, profitability and liquidity in accordance with pecking order theory. In particular, fixed ratio has a negative effect on debt ratio in Russia and Romania, but no effect in other countries under study. The effect of size disappears when time dummy variables are introduced.
\end{abstract}

\section{Introduction}

How and when firms choose external financing, or choose capital structure, is a heavily researched topic. Since the discovery of the irrelevance of the capital structure on the firm value under perfect markets and absence of taxes, researchers have investigated factors which may affect the capital structure decision.

Static tradeoff theory argues there are costs and benefits of debt. In particular, costs of debt include the direct and indirect costs of bankruptcy, while the benefits include tax deductibility of interest expenses. By analyzing the benefits and costs, firms choose an optimal leverage and try to maintain this ratio in their balance sheet. Assuming insiders know more about the company than outsiders, pecking order theory argues firms prefer internal financing, and when external financing is required, they choose debt over equity without any target or optimal leverage. The two theories may give different predictions, which may yield testable hypotheses. For example highly profitable firms would not need external financing, so would not raise debt according to pecking order theory. However, according to tradeoff theory, for highly profitable firms, bankruptcy costs are lower, so they would have an incentive to issue debt. Empirical studies find support for target leverage (Bradley, etal, 1984) and also support for pecking order; a negative relation of profitability with market debt ratio (debt/market value of equity) (Titman and Wessels, 1988).

Especially the studies on developing countries, the results of the studies have been less conclusive. The results typically change with sectors and time period under investigation. Mismeasured variables pose a threat to the validity of tests, the role of other stakeholders and supply side of capital should be investigated more (Graham and Leary, 2011).

Construction sector is a particular sector, which requires large initial capital outlays, project life times and cash payments are typically long term. This study examines the effects of asset tangibility, profitability, size and liquidity on debt ratio for construction companies in Europe and Central Asia Region which mostly comprises of developing countries. Asset tangibility, profitability and liquidity are found to be negatively associated with higher leverage consistent with pecking order theory. Moreover, the negative relation between debt ratio and asset tangibility comes from the companies in Russia and Romania.

The paper is organized as follows. Section 2 reviews the literature, Section 3 discusses the model and hypotheses, Section 4 presents the data and descriptive statistics and Section 5 presents and discusses the results.

\section{Literature Review}

Under perfect capital markets and absence of taxes, it has been shown that debt ratio does not change the value of the company (Modigliani and Miller, 1958). Static tradeoff theory emerged in which costs of debt, such as bankruptcy, are balanced against benefits, such as tax shields associated interest payments provide, in order to obtain an optimal debt structure (Kim, 1978) (Lee and Barker, 1977). In pecking order theory, firms prefer internal financing to external financing, and in the latter, prefer issuing debt to equity, due to the information asymmetry between owners and the market (Myers, 1984). Agency cost theory posits that firms may increase their debt to reduce the free cash flow by increasing interest expense to alleviate the agency problem between owners and managers (Jensen and Meckling, 1976). According to market timing theory, firms sell shares when they believe the stock price is high, and engage in share buybacks when the stock price is low, and the effects of these actions have persistent effects on the capital structure (Baker and Wurgler, 2002).

There is an extended literature on testing these theories empirically, with some shortcomings withstanding (Graham and Leary, 2011). Based on the data between 1996 and 2004 on 15 EU countries on construction sector, firm size is positively related to debt and market leverage. Asset utilization, profitability and risk (profit variability) are negatively related, while liquidity and asset tangibility are not significantly related. Growth opportunities are negatively related to book leverage but positively with market leverage (Feidakis and Rovolis, 2007). 
In UK companies between 1984 and 1996, profitability, liquidity and growth opportunities are found to be negatively related to debt ratio, while size has no effect (Ozkan, 2001). Using the data on UK companies between 1989 and 1996, it is found that property asset intensity, development activities are positively, and trading activities and size are negatively related to book leverage (Ooi, 1999).

Using the cross sectional data from France, Germany, Japan, the UK, and the US of 1992 or 1993, it has been found that asset tangibility has a positive and profitability has a negative effect on leverage across all countries. The effect of size is positive for US, UK and Japan but insignificant in Germany and France (Wald, 1999).

Cross industry studies, especially on construction sector, on capital structure are less numerous. In a cross industry study based on US construction companies, market-to-book ratio, profitability and firm age are found to be negatively related to leverage (measured as long term debt to assets), and firm size is positively related to leverage (Talberg, et.al., 2008).

There are also studies on construction sector in developing markets. Construction sector differs from other sectors in that the projects undertaken are usually long term and require significant capital outlays.

The evidence on the effects of firm variables on leverage is largely inconclusive in developing markets. Based on the data between 2000 and 2010 of construction companies in South Korea, firm size has a positive effect while profitability and asset tangibility negatively affects book leverage (Yoo, et.al., 2014). In Malaysia, based on the data between 2001 and 2007, firm sales (proxy for size), asset tangibility and growth opportunities have positive effect on leverage, while profitability has a negative effect on leverage (Baharuddin, et.al.,2011). Another study in Malaysia using the data between 2005 and 2009 found profitability is positively related and asset growth is negatively related to leverage (Ramezanalivaloujerdi, et.al., 2015). Between 2002 and 2011, on book leverage, firm size has a negative effect in Russia, positive effect in India. Asset tangibility and firm size positively affects leverage in India, while growth opportunities has a negative effect. In China, asset tangibility is found to have a positive effect. The size and significance of these effects depend on the debt level of companies (Silva, et.al., 2016). Based on the construction company data in Indonesian Stock Exchange between 2009 and 2014, profitability increases the debt ratio (Gunardi, 2020). Asset tangibility is significantly negatively correlated with book leverage on Omani listed construction companies (Al Ani and Al Amri, 2005). Profitability, liquidity and asset tangibility are negatively, size and asset turnover are positively related to debt ratio in Romanian construction companies (Serghiescu and Văidean, 2014). A study based on Slovenian firms between 1999 and 2006 finds asset tangibility and profitability are negatively related to book leverage, while size is positively related (Črnigoj and Mramor, 2009).

\section{Model and Methodology}

A fixed effect panel data model was employed as follows.

$$
\begin{aligned}
& \text { Book Leverage }_{i t}=\beta_{1} \text { LogFixedAssetRati o }_{\text {it }}+\beta_{2} \text { EBITTA }_{\text {it }}+\beta_{3} \text { LogAssets } \\
& +\beta_{4} \text { LogLiquidity }+u_{i}+v_{t}+\varepsilon_{i t}
\end{aligned}
$$

Depending on the postestimation tests performed, random effects and OLS were also employed where the associated diagnostic tests of corresponding models failed.

The variables are book leverage (debt ratio=total liabilities/total assets), asset tangibility (fixed asset ratio=plant property and equipment over total assets), profitability ratio (EBIT over TA), size (log(assets)), liquidity (current ratio) and operating leverage (percentage change in EBIT over percentage change in sales). All of the variables were computed using only balance sheet and income statement data. Fixed asset ratio, assets as well as liquidity was transformed by log function, which will be explained in the later section.

From a tradeoff theory standpoint, fixed asset ratio is expected to positively affect leverage, as companies with more fixed assets may find it easier to access debt. On the other hand, companies with higher fixed asset ratio have lower cash, and thus lower agency costs. Therefore, they have less incentive to issue debt, from an agency cost perspective. From a pecking order viewpoint, companies with more fixed assets than intangible assets may have less information asymmetry between the owners and market, and may use more equity.

Highly profitable (EBIT/TA ratio) companies, according to tradeoff theory, will have more incentive to keep higher levels of debt to utilize tax shields. Also, from the agency cost theory perspective, these companies have more excess cash and has more incentive to reduce the excess cash through higher debt. From the pecking order viewpoint, these companies have lower motives to seek external financing so their debt ratio would be lower.

According to tradeoff theory, larger (more assets) companies have more debt since these firms are typically more diversified, so the bankruptcy risk is smaller, reducing the cost of debt. Since these companies are monitored more by the market participants and regulatory authorities, there exists less information asymmetry between the owners and managers. So, according to agency cost theory, they have less incentive to issue debt.

Companies with higher liquidity (current ratio) may have lower probability of bankruptcy or even may use working capital to secure financing, thus lowering the cost of debt. So they have more incentive to take on debt 
according to tradeoff theory. From an agency cost perspective, these companies have more cash. So, to solve the agency problem between owners and managers, they have an incentive to take on more debt. From a pecking order standpoint, they have more internal resources and thus have less incentive to seek outside resources, and thus have lower debt.

\section{Data}

Corporate financial data of construction companies (listed and delisted) with assets more than 3 million USD in Europe and Central Asia region was downloaded from EMIS Database. The data for which any of the variables under study is missing was dropped. The final dataset contains 2607 company-year observations of 184 companies from 16 countries from 1993 to 2019 . The data is winsorized at $1 \%$ from both sides.

Table 1 shows the means of variables by country, and number of companies in each country. Financial ratios differ across countries even if they are all in construction sector. Comparing Romanian construction companies with other studies leverage is higher, fixed asset ratio is smaller, size is smaller (Serghiescu, L. and Văidean, 2014). Book leverage is larger than reported in another study focusing on Russia, however this study focuses on construction companies (Silva, et.al., 2016). The data on Poland are similar to another study which focuses on all sectors.

\begin{tabular}{|c|c|c|c|c|c|c|c|c|c|}
\hline & $\begin{array}{l}\text { No of } \\
\text { comp. }\end{array}$ & No of obs & Min year & Max year & $\begin{array}{l}\text { Avg Debt } \\
\text { to asset } \\
\text { ratio }\end{array}$ & $\begin{array}{c}\text { Avg } \\
\text { Fixed } \\
\text { Asset } \\
\text { Ratio }\end{array}$ & $\begin{array}{c}\text { Avg } \\
\text { Current } \\
\text { Ratio }\end{array}$ & $\begin{array}{c}\text { Avg } \\
\text { EBIT/TA } \\
\text { ratio }\end{array}$ & $\begin{array}{c}\text { Log } \\
\text { (Asts) }\end{array}$ \\
\hline Bulgaria & 4 & 63 & 2001 & 2019 & 0.37 & 0.15 & 3.79 & 0.03 & 9.76 \\
\hline Croatia & 6 & 97 & 1999 & 2019 & 0.65 & 0.35 & 1.08 & -0.00 & 11.06 \\
\hline Estonia & 2 & 6 & 2008 & 2016 & 0.19 & 0.01 & 13.93 & 0.02 & 11.02 \\
\hline Kazakhstan & 1 & 9 & 2010 & 2018 & 0.20 & 0.75 & 1.97 & 0.10 & 14.72 \\
\hline Latvia & 1 & 9 & 2007 & 2015 & 0.40 & 0.19 & 0.70 & 0.18 & 10.15 \\
\hline Lithuania & 1 & 4 & 2006 & 2010 & 0.01 & 0.00 & 1.79 & 0.11 & 11.25 \\
\hline Moldova & 1 & 2 & 2017 & 2018 & 0.46 & 0.54 & 1.06 & 0.00 & 8.66 \\
\hline Montenegro & 1 & 2 & 2017 & 2018 & 0.08 & 0.32 & 8.39 & -0.01 & 10.18 \\
\hline North Macedonia & 4 & 41 & 2006 & 2019 & 0.49 & 0.25 & 1.28 & 0.01 & 10.73 \\
\hline Poland & 81 & 1326 & 1993 & 2019 & 0.46 & 0.12 & 3.16 & 0.04 & 10.36 \\
\hline Romania & 13 & 165 & 2005 & 2019 & 0.54 & 0.44 & 2.59 & 0.02 & 9.19 \\
\hline Russia & 37 & 474 & 2001 & 2019 & 0.67 & 0.13 & 1.85 & 0.05 & 11.39 \\
\hline Serbia & 2 & 25 & 2005 & 2018 & 0.54 & 0.30 & 1.32 & 0.07 & 9.04 \\
\hline Slovakia & 8 & 149 & 1995 & 2019 & 0.45 & 0.33 & 2.55 & 0.04 & 9.73 \\
\hline Turkey & 9 & 88 & 2005 & 2019 & 0.48 & 0.19 & 2.04 & 0.04 & 11.49 \\
\hline Ukraine & 13 & 147 & 2001 & 2019 & 0.74 & 0.18 & 2.38 & 0.02 & 10.51 \\
\hline $\mathrm{N}$ & 184 & 2607 & 1993 & 2019 & & & & & \\
\hline
\end{tabular}

Table 1. Descriptive Statistics by Countries Source: Author's Own Calculations.

Table 2 shows the correlations between the variables. Debt to asset ratio is negatively correlated with fixed asset ratio (asset tangibility), current ratio (liquidity), and EBIT/TA ratio (profitability), in accordance with pecking order, but positively related to assets (size), in accordance with tradeoff theory. Other studies with developing markets found similar correlations with respect to profitability and size of Oman companies (Al Ani and Al Amri, 2015), and size, fixed asset ratios, profitability and liquidity of South Korean companies (Choi, et.al., 2014). Companies with higher fixed assets tend to have lower liquidity (current ratio), lower profitability (EBIT/TA) and be smaller in size.

\begin{tabular}{llllll}
\hline & $\begin{array}{l}\text { Debt to asset } \\
\text { ratio }\end{array}$ & Fixed asset ratio & Current ratio & $\begin{array}{l}\text { EBIT/TA } \\
\text { ratio }\end{array}$ & $\begin{array}{l}\text { Log } \\
\text { (asset) }\end{array}$ \\
\hline Debt to asset ratio & 1.00 & & & & \\
Fixed asset ratio & $-0.03^{*}$ & 1.00 & & & \\
Current ratio & $-0.42^{* * *}$ & $-0.17^{* * *}$ & 1.00 & & \\
EBIT/TA ratio & $-0.04^{*}$ & $-0.06^{* * *}$ & $-0.07 * * *$ & 1.00 & 1.00 \\
Log(asset) & $0.20^{* * *}$ & $-0.26^{* * *}$ & $-0.04 * *$ & -0.01 & \\
\hline$t$ statistics in parentheses $* p<0.1, * * p<0.05, * * * p<0.01$ & & &
\end{tabular}

Table 2. Correlations of Variables Source: Author's Own Calculations.

Table 3 shows the descriptive statistics of the variables under study. Debt to asset (leverage) ratios are similar to other studies in developing countries; 0.60 in construction sectors in South Korea (Choi, et.al., 2014), 0.59-0.63 in Slovenia (Črnigoj and Mramor, 2009). The variables fixed asset ratio and current ratio has been transformed by 
natural log, as they exhibit a high degree of skewness. The transformed variables show better properties in terms of range and skewness.

\begin{tabular}{|c|c|c|c|c|c|c|c|c|}
\hline & $\mathrm{N}$ & Mean & St.Dev. & Min & $25 \%$ & $\begin{array}{c}50 \% \\
\text { (Median) } \\
\end{array}$ & $75 \%$ & Max \\
\hline Debt to asset ratio & 2607 & 0.52 & 0.26 & 0.01 & 0.33 & 0.54 & 0.72 & 0.98 \\
\hline Fixed asset ratio & 2607 & 0.18 & 0.21 & 0.00 & 0.01 & 0.10 & 0.27 & 0.82 \\
\hline $\begin{array}{l}\log (\text { Fixed asset } \\
\text { ratio) }\end{array}$ & 2607 & 0.15 & 0.16 & 0.00 & 0.01 & 0.10 & 0.24 & 0.60 \\
\hline EBIT/TA ratio & 2607 & 0.04 & 0.09 & -0.26 & -0.00 & 0.03 & 0.08 & 0.37 \\
\hline $\log ($ asset $)$ & 2607 & 10.50 & 1.74 & 6.66 & 9.21 & 10.49 & 11.68 & 15.00 \\
\hline Current ratio & 2607 & 2.67 & 4.64 & 0.04 & 1.02 & 1.39 & 2.34 & 32.32 \\
\hline $\log ($ Current ratio) & 2607 & 1.03 & 0.60 & 0.04 & 0.70 & 0.87 & 1.21 & 3.51 \\
\hline Observations & 2607 & & & & & & & \\
\hline
\end{tabular}

Table 3. Descriptive Statistics Source: Author's Own Calculations.

\section{Results}

Table 4 shows the results of the regressions. Columns (1) to (3) show results without time dummy variables, and columns (4) to (6) show results with time dummy variables. Based on the diagnostic tests shown, model (6) passes the diagnostic tests. Other regressions results are displayed, since by using fixed effects in (6) cross country variation in leverages would be omitted, and the results are the same without the fixed effects.

In all specifications, debt ratio is negatively related to fixed asset ratio (asset tangibility), EBIT/TA ratio (profitability) and log of current ratio (liquidity), but positively related to size. The results are consistent with the findings in the literature for construction companies (Yoo, et.al., 2014) and Slovenia (Črnigoj and Mramor, 2009), but not studies on Malaysia (Baharuddin, et.al.,2011) (Ramezanalivaloujerdi, et.al., 2015), India and China (Silva, et.al., 2016).

These results are largely consistent with Pecking Order framework, except size. Similar conclusion are reached by a study on Polish companies (Mazur, 2007). In Table 4, in the regression with time dummies (6) size loses significance, and time effects are significant. This shows it is important to add time covariates into leverage regressions (Feidakis and Rovolis, 2007) (Gunardi, et.al.,2020).

\begin{tabular}{|c|c|c|c|c|c|c|}
\hline $\begin{array}{l}\text { Dependent variable } \\
\text { Debt to asset ratio }\end{array}$ & (1) & $(2)$ & (3) & (4) & $(5)$ & $(6)$ \\
\hline \multirow[t]{2}{*}{ Log(Fixed asset ratio) } & $-0.17 * * *$ & $-0.14 * *$ & $-0.14 * *$ & $-0.19 * * *$ & $-0.16 * *$ & $-0.16 * *$ \\
\hline & $(0.03)$ & $(0.06)$ & $(0.07)$ & $(0.03)$ & $(0.06)$ & $(0.07)$ \\
\hline \multirow[t]{2}{*}{ EBIT/TA ratio } & $-0.12 * * *$ & $-0.23 * * *$ & $-0.24 * * *$ & $-0.12 * *$ & $-0.23 * * *$ & $-0.25 * * *$ \\
\hline & $(0.05)$ & $(0.06)$ & $(0.06)$ & $(0.05)$ & $(0.06)$ & $(0.07)$ \\
\hline \multirow[t]{2}{*}{ Log(Asset) } & $0.02 * * *$ & $0.02 * *$ & $0.01 *$ & $0.02 * * *$ & $0.02 * *$ & 0.02 \\
\hline & $(0.00)$ & $(0.01)$ & $(0.01)$ & $(0.00)$ & $(0.01)$ & $(0.01)$ \\
\hline \multirow[t]{2}{*}{ Log(Current ratio) } & $-0.24 * * *$ & $-0.17 * * *$ & $-0.16^{* * *}$ & $-0.25 * * *$ & $-0.17 * * *$ & $-0.16^{* * *}$ \\
\hline & $(0.01)$ & $(0.02)$ & $(0.02)$ & $(0.01)$ & $(0.02)$ & $(0.02)$ \\
\hline Company effects & No & Yes (re) & Yes (fe) & No & Yes (re) & Yes (fe) \\
\hline Time dummy vars & No & No & No & Yes & Yes & Yes \\
\hline Observations & 2607 & 2607 & 2607 & 2607 & 2607 & 2607 \\
\hline$R^{2}$ & 0.35 & & 0.20 & 0.37 & & 0.21 \\
\hline Adjusted $R^{2}$ & 0.35 & & 0.20 & 0.36 & & 0.20 \\
\hline $\mathrm{F}$ & $351.59 * * *$ & & 25.11 & 49.88 & & \\
\hline $\mathrm{N}$ (groups) & & 184 & 184 & & 184 & 184 \\
\hline Hausmann test stat & & & $46.33 * * *$ & & & $108.71 * * *$ \\
\hline (df) & & & (4) & & & (30) \\
\hline Wald test for heterosce. & & & $1.6 \mathrm{e}+33 * * *$ & & & $1.0 \mathrm{e}+33 * * *$ \\
\hline (df) & & & (184) & & & (184) \\
\hline $\begin{array}{l}\text { Breusch Pagan LM test for } \\
\text { random effects }\end{array}$ & & $2463.84 * * *$ & & & $2194.96 * * *$ & \\
\hline Joint test for time effects & & & & $2.60 * * *$ & $263.04 * * *$ & $7.45 * * *$ \\
\hline$(\mathrm{df} 1, \mathrm{df} 2)$ or $(\mathrm{df})$ & & & & $(26,2576)$ & (26) & $(26,183)$ \\
\hline
\end{tabular}

Robust standard errors in parentheses $* p<0.1$, ** $p<0.05, * * * p<0.01$

Table 4. Regression Results of Debt to Assets Ratio Source: Author's Own Calculations

Table 5 shows the separate regression results for the largest countries in the sample. For each country different methods were used as suggested by the diagnostic tests. In particular, as the number of groups in countries drop, it became harder to estimate time dummy variables under heteroscedasticity. 
In Table 5, Russia and Romania are the countries where fixed asset ratio negatively affects the debt ratio, while in other countries the effect is statistically insignificant. This is consistent with the OLS regressions of the Romania study (Serghiescu and Văidean, 2014), but not with the study on Russia (Silva, et.al., 2016). This may be due to Russian and Romanian construction companies utilizing more fixed assets (median fixed asset ratios are 9\% and $44 \%$ respectively) compared to other countries like Poland (4\%).

Profitability (EBIT/TA ratio) loses significance in Russia, Romania and Turkey. Also, liquidity (current ratio) is negatively related to debt ratio in all countries except Romania. These two results may be due to reduced sample size.

\begin{tabular}{|c|c|c|c|c|c|}
\hline $\begin{array}{l}\text { Dependent variable } \\
\text { Debt to asset ratio }\end{array}$ & $\begin{array}{l}\text { Poland } \\
\text { (1) }\end{array}$ & $\begin{array}{l}\text { Russia } \\
\text { (2) }\end{array}$ & $\begin{array}{l}\text { Romania } \\
\text { (3) }\end{array}$ & $\begin{array}{l}\text { Turkey } \\
\text { (4) }\end{array}$ & $\begin{array}{l}\text { Others } \\
(5)\end{array}$ \\
\hline $\log$ (Fixed asset ratio) & $\begin{array}{c}0.04 \\
(0.09)\end{array}$ & $\begin{array}{c}-0.34 * * * \\
(0.12)\end{array}$ & $\begin{array}{c}-0.58 * * * \\
(0.16)\end{array}$ & $\begin{array}{l}-0.18 \\
(0.14)\end{array}$ & $\begin{array}{l}-0.23 \\
(0.22)\end{array}$ \\
\hline EBIT/TA ratio & $\begin{array}{c}-0.18 * * \\
(0.08)\end{array}$ & $\begin{array}{l}-0.19 \\
(0.13)\end{array}$ & $\begin{array}{l}-0.30 \\
(0.25)\end{array}$ & $\begin{array}{l}0.04 \\
(0.09)\end{array}$ & $\begin{array}{l}-0.39 * \\
(0.23)\end{array}$ \\
\hline Log(Asset) & $\begin{array}{c}0.02 \\
(0.01)\end{array}$ & $\begin{array}{c}0.02 \\
(0.02)\end{array}$ & $\begin{array}{l}-0.10 \\
(0.07)\end{array}$ & $\begin{array}{c}0.03 * * \\
(0.01)\end{array}$ & $\begin{array}{c}0.01 \\
(0.02)\end{array}$ \\
\hline Log(Current ratio) & $\begin{array}{c}-0.16^{* * * *} \\
(0.02)\end{array}$ & $\begin{array}{c}-0.21 * * * \\
(0.05)\end{array}$ & $\begin{array}{l}-0.10 \\
(0.06)\end{array}$ & $\begin{array}{c}-0.35 * * * \\
(0.09)\end{array}$ & $\begin{array}{c}-0.08 * * * \\
(0.03)\end{array}$ \\
\hline Company effects & Yes (fe) & Yes (re) & Yes (re) & No & Yes (fe) \\
\hline Time fixed effects & No & No & No & No & No \\
\hline Observations & 1326 & 474 & 165 & 88 & 466 \\
\hline$R^{2}$ & 0.25 & 0.28 & 0.18 & 0.29 & 0.19 \\
\hline Adjusted $R^{2}$ & 0.25 & 0.28 & 0.16 & 0.25 & 0.18 \\
\hline $\mathrm{F}$ & 16.84 & 15.81 & 10.02 & 21.25 & 5.40 \\
\hline $\mathrm{N}$ groups & 81 & 37 & 13 & 9 & 41 \\
\hline
\end{tabular}

Table 5. Regression Results of Debt to Assets Ratio by Countries Source: Author's Own Calculations.

\section{Conclusion}

In this study, the effects of asset tangibility (fixed asset ratio), profitability (EBIT to total assets), size (assets) and liquidity (current ratio) on capital structure are examined for the listed and delisted construction companies in European and Central Asian region.

Debt ratio is significantly negatively related to asset tangibility, profitability and liquidity. The significance of size drops when time dummies are introduced, which shows the importance of adding time varying covariates. The results provide support for pecking order theory of capital structure.

Country-wise regressions show that negative effect of asset tangibility arise from Russia and Romania, while it is not present in Poland and other countries.

\section{References}

- $\quad \mathrm{Al}$ Ani and Al Amri, 2015. "The determinants of capital structure: an empirical study of Omani listed industrial companies", Business: Theory and Practice, 16(2), p.159.

- Baharuddin, Khamis, Mahmood and Dollah, 2011. "Determinants of capital structure for listed construction companies in Malaysia", Journal of Applied Finance and Banking, 1(2), p.115.

- Baker and Wurgler, 2002. "Market timing and capital structure", The Journal of Finance, 57(1), p.1.

- Bradley, Jarrell and Kim, 1984. "On the existence of an optimal capital structure: Theory and evidence", The Journal of Finance, 39(3), p.857.

- Choi, Yoo, Kim and Kim, 2014. "Capital structure determinants among construction companies in South Korea: A quantile regression approach”, Journal of Asian Architecture and Building Engineering, 13(1), p.93.

- Črnigoj and Mramor, 2009. "Determinants of capital structure in emerging European economies: Evidence from Slovenian firms", Emerging Markets Finance and Trade, 45(1), p.72.

- Feidakis and Rovolis, 2007. "Capital structure choice in European Union: evidence from the construction industry”, Applied Financial Economics, 17(12), p.989.

- Graham and Leary, 2011. "A Review of Empirical Capital Structure Research and Directions for the Future”, Annual Review of Financial Economics, 3(1), p.309.

- Gunardi, Firmansyah, Widyaningsih, and Rossi, 2020. "Capital Structure Determinants of Construction Firms: Does Firm Size Moderate the Results?”, Montenegrin Journal of Economics, 16(2), p.93. 
- Jensen and Meckling, 1976. "Theory of the firm: Managerial behavior, agency costs and ownership structure", Journal of Financial Economics, 3(4), p.305.

- Kim, 1978. "A mean-variance theory of optimal capital structure and corporate debt capacity", The Journal of Finance, 33(1), p.45.

- Lee and Barker, 1977. "Bankruptcy costs and the firm's optimal debt capacity: a positive theory of capital structure", Southern Economic Journal, p.1453.

- Mazur, 2007. "The determinants of capital structure choice: evidence from Polish companies", International Advances in Economic Research, 13(4), p.495.

- Miller, 1977. "Debt and taxes", The Journal of Finance, 32(2), p.261.

- Modigliani and Miller, 1958. "The cost of capital, corporation finance and the theory of investment", The American Economic Review, 48(3), p.261.

- Myers, 1984. “The Capital Structure Puzzle” The Journal of Finance, 39(3), p.574.

- Ooi, 1999. “The determinants of capital structure Evidence on UK property companies”, Journal of Property Investment and Finance, 17(5), p.464.

- Ozkan, 2001. "Determinants of capital structure and adjustment to long run target: evidence from UK company panel data", Journal of Business Finance \& Accounting, 28(1-2), p.175.

- Ramezanalivaloujerdi, Rasiah and Narayanasamy, 2015. "Corporate capital structure and performance of listed construction companies in Malaysia from 2005-2009”, International Business Management, 9(3), p.191.

- Serghiescu and Văidean, 2014. "Determinant factors of the capital structure of a firm-an empirical analysis", Procedia Economics and Finance, 15, p.1447.

- Silva, Santos, Perobelli and Nakamura, 2016. "Capital structure of Brazil, Russia, India and China by economic crisis", RAM. Revista de Administração Mackenzie, 17(3), p.105.

- Talberg, Winge, Frydenberg and Westgaard, 2008. "Capital structure across industries", International Journal of the Economics of Business, 15(2), p.181.

- Titman and Wessels, 1988. "The determinants of capital structure choice”, The Journal of Finance, 43(1), p.1.

- Wald, 1999. "How firm characteristics affect capital structure: an international comparison", Journal of Financial research, 22(2), p.161. 